\title{
/ILTERIN/ITOR
}

Misliti znanost.

\section{Psihologija in robotika: načrtovanje interakcij s sodelujočim robotom}

\section{5. 2021}

Številka: 30/2021

Avtorica:

- Kristina Rakinić

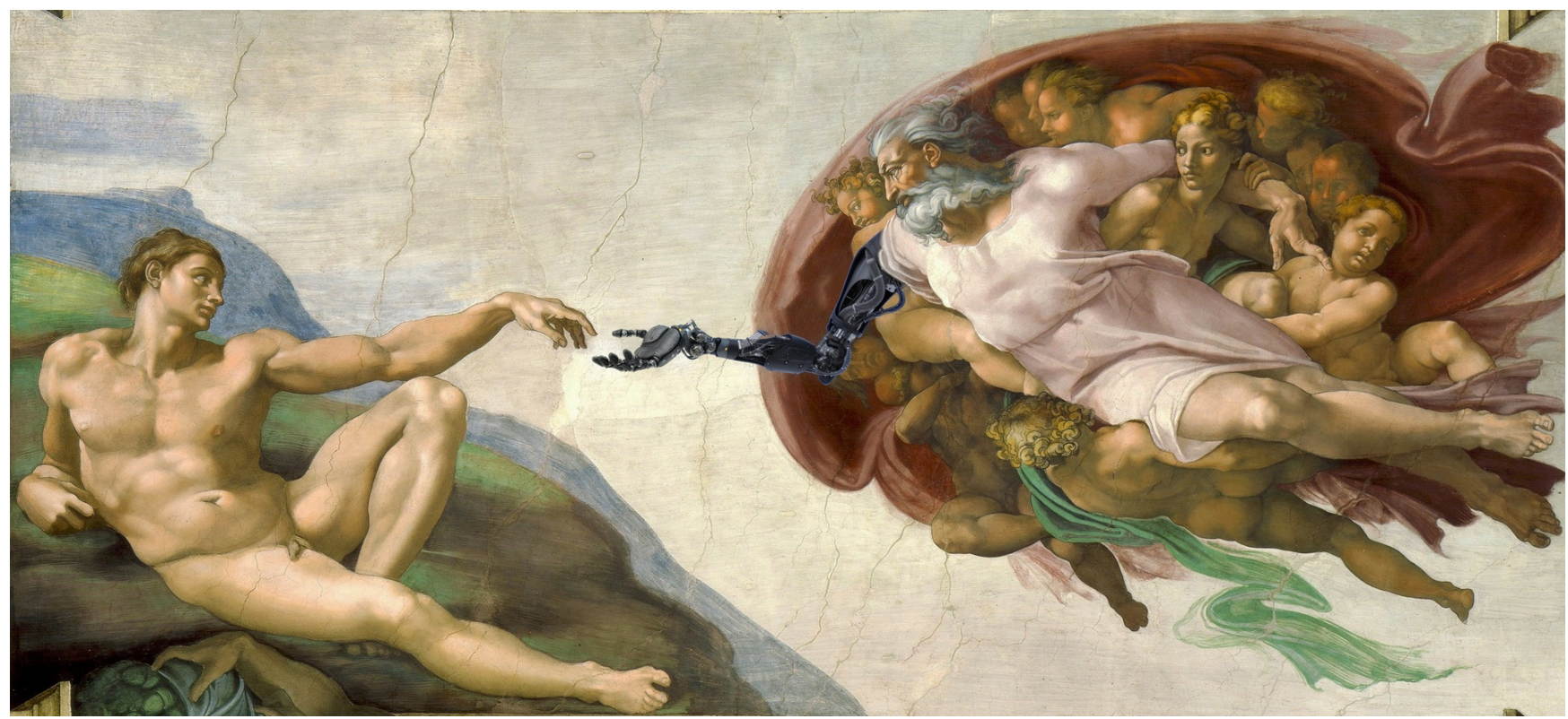

Računalniška obdelava: Katja Bidovec

»S čim se pa ti ukvarjaš? « »Raziskujem interakcijo med človekom in robotom. « Temu odgovoru običajno sledita dva, skoraj nasprotna si odziva. Če eden odraža navdušenje in zanimanje zaradi aktualnosti robotike, drugi s precej manj besedami odraža neko nelagodje, za katerim najverjetneje stoji strah pred neznanim. Odnos med človekom in robotom je bil od nekdaj ambivalenten, saj smo se ljudje po eni strani s pomočjo robotov osvobodili težaškega, nevarnega in monotonega dela, po drugi strani pa se bojimo, da bodo roboti prevzeli naše delo. Namen prispevka je predstaviti sodelujoče robote in osvetliti tiste psihološke dejavnike, ki vplivajo na sprejemanje robotov.

\section{Kratka opredelitev robota}

Lansko leto smo praznovali stoto obletnico prve omembe besede robot. Prvi jo je uporabil Karl Čapek v svoji drami $\underline{R}$.U.R. (https://plus.si.cobiss.net/opac7/bib/25842177) (Rossumovi Univerzální Robott) iz leta 1921. V drami je zapisal, da roboti niso ljudje in čeprav so mehanično popolnejši od nas, imajo silno moč razuma, a nimajo duše. Beseda robot izhaja iz češke besede robota in pomeni »prisilno delo«. Besedo je skoval Karlov brat Josef, slikar in pesnik. Kljub omenjenemu ne moremo reči, da so roboti del naše družbe oziroma predmet našega razmišljanja zgolj zadnjih 100 let. Začetki robotike in avtomatizacije segajo daleč nazaj v človeško zgodovino (https://pubmed.ncbi.nlm.nih.gov/25811686/). Robotika je v zadnjih desetletjih, torej $v$ času izjemno hitrega tehnološkega razvoja, doživela velik razcvet. Robotika je znanstvena veda, ki se ukvarja z načrtovanjem, oblikovanjem in uporabo strojev (robotov) z namenom, da ti opravijo določene delovne naloge. Ameriški inštitut za robotiko robota opredeli kot reprogramibilnega, večnamenskega manipulatorja, ki na osnovi različnih programiranih gibov premika materiale, polizdelke, orodja in specializirane naprave ter s tem opravlja določene delovne naloge. $V$ zadnjem času se razvija čedalje več neindustrijskih robotov, ki so namenjeni profesionalni rabi, a jih lahko uporabljajo strokovnjaki, ki niso robotiki (npr. sodelujoči roboti v laboratorijih ipd.), in za domačo uporabo. Hkrati pa se pojavlja vedno več robotov, ki jim lahko rečemo socialni roboti (Hegel idr. 2009

(https://ieeexplore.ieee.org/abstract/document/4782510)). Slednji so namenjeni neposredni pomoči ljudem (npr. starostnikom), hkrati pa lahko (vsaj delno) zadovoljijo tudi potrebo po druženju. Robotika vedno bolj postaja interdisciplinarna veda, tako ima pri razvoju in programiranju robotov pomembno vlogo tudi psihologija, ki lahko s poznavanjem človeškega vedenja pripomore, da je človekova izkušnja z robotom učinkovitejša in prijetnejša. Že leta 1942 je Isaac Asimov v svojem delu Runaround zapisal tri zakone robotike, po katerih bi morali delovati roboti, da bi lahko bivali 
v sožitju z ljudmi. Prvi zakon predpostavlja, da robot nikoli ne sme poškodovati ali delovati v škodo ljudem, drugi, da mora robot upoštevati ukaze ljudi, vendar ne v primerih, ko bi taki ukazi bili v nasprotju s prvim zakonom in tretji zakon, ki govori o tem, da mora robot varovati svoj lastni obstoj, razen, ko je to v nasprotju s prvim in drugim zakonom.

\section{Sodelujoči roboti}

Sodelujoči (angl. collaborative) roboti so zasnovani z namenom, da človeka prek sodelovalne interakcije razbremenijo opravljanja enostavnih, nevarnih in monotonih delovnih nalog oziroma posameznih faz delovnega procesa, pri katerem sodelujeta. Za razliko od klasičnih industrijskih robotov sodelujoči opravljajo delo neposredno skupaj z ljudmi in si z njimi tudi delijo delovni prostor. Prvi sodelujoči roboti so se pojavili v 90. letih prejšnjega stoletja, do leta 2025 pa naj bi predstavljali kar 34 odstotkov (https://www.automate.org/blogs/collaborative-robots-market-update-2018) vseh prodanih robotov. Za »očeta sodelujočih robotov veljata inženirja Ł. Edward Colgate in Michael A. Peshkin (https://www.engineering.com/story/a-history-of-collaborative-robots-from-intelligent-lift-assists-to-cobots). Oblikovala sta jih, da bi razbremenila delavce pri zahtevnih opravilih, ki pogosto terjajo poškodbe pri delu. Glavna prednost sodelujočih robotov je, da so relativno enostavni za upravljanje in da se lahko v službi »učijo«. Delavci jih lahko premikajo in vodijo do določene točke, roboti pa si to pot zapomnijo in jo naslednjič opravijo sami.

Mednarodna zveza za robotiko (https://www.ppma.co.uk/uploads/assets/5e46c1b9-cd23-423ea59650c216e54a0f/ifrdemystifyingcollaborativerobotsupdate2019.pdf) (2019) definira štiri različne načine sodelovanja med sodelujočimi roboti in ljudmi:

- Človek in robot delata drug ob drugem, vendar si ne delita skupnega delovnega prostora (sta zgolj v istem prostoru).

- Človek in robot si delita delovni prostor, vendar ne delata skupaj pri določeni delovni nalogi ali napravi (zaporedno sodelovanje).

- Človek in robot delata hkrati pri isti delovni nalogi in sta oba v gibanju.

- Odzivno sodelovanje: robot se na gibanje človeka odziva v realnem času.

Trenutno najpogostejši vrsti sodelovanja v praksi sta prvi dve, saj ju v primerjavi s tretjim in četrtim načinom sodelovanja veliko lažje načrtujemo in izvajamo. Inženirji morajo pri načrtovanju in vključevanju sodelujočih robotov na delovna mesta upoštevati tudi posebne standarde varnosti. ISO/TS 15066 (https://blog.robotiq.com/what-is-isots-15066) je dokument, ki vsebuje smernice za varno delovanje sodelujočih robotov. Izhaja iz standarda ISO 10218 (1. in 2. del), ki predstavlja zahteve za varno delovanje industrijskih robotov in temelji na ideji, da sodelujoči robot v primeru fizičnega stika $\mathrm{s}$ človekom le-temu ne sme povzročiti bolečin ali poškodb. $V$ smernicah so navedene tako najvišje priporočene hitrosti, $s$ katerimi se roboti lahko premikajo, kot tudi predlogi za vključevanje dodatnih senzorjev v robote, ki v primeru prevelike sile stika med človekom in robotom sprožijo njihovo avtomatično in hitro ustavitev.

\section{Psihološki pogled na interakcijo med človekom in robotom}

Za učinkovitost interakcije robota in človeka sta ključna dva psihološka fenomena: zaznana varnost (https://dl.acm.org/doi/10.1145/2658861.2658871) robota in zaupanje (https://www.elsevier.com/books/trust-in-humanrobot-interaction/nam/978-0-12-819472-0) v interakcijo z robotom. Dejavnike, ki vplivajo na zaupanje, sprejemanje robotov in njihovo zaznano varnost lahko $v$ grobem razdelimo na psihološke dejavnike (npr. spol, starost, osebnostne značilnosti), značilnosti robotov (npr. stopnja predvidljivosti gibov, hitrost premikanja) in situacijske dejavnike (npr. zahtevnost delovne naloge). $V$ delovnem kontekstu oziroma v resnični situaciji vsi ti dejavniki delujejo skupaj, tj. v medsebojni interakciji. Mnoge raziskovalce je zanimalo, ali lahko zgolj s poznavanjem demografskih značilnosti posameznikov odgovorijo na vprašanje, katere skupine ljudi imajo bolj pozitivna stališča do robotov in jim posledično tudi bolj zaupajo. Ugotovili so, da so ti v večini mladi (https://link.springer.com/article/10.1007/s12369-010-0068-5), moški (https://www.sciencedirect.com/science/article/pii/S0747563218305806?via\%3Dihub) in posamezniki, ki študirajo oziroma opravljajo poklic na naravoslovnem ali tehničnem področju (https://www.jbe-

platform.com/content/journals/10.1075/is.10.3.05nom). Pomembno področje psihologije je raziskovanje osebnosti. Eden najbolj razširjenih modelov osebnosti je model velikih pet oziroma petih temeljnih osebnostnih značilnosti: ekstravertnost (komunikativnost, energičnost, težnja k vzpostavljanju socialnih stikov), nevrotizicem (nagnjenost k zaskrbljenosti, tesnobi, negativnemu čustvovanju in zaprtosti), vestnost (težnja k vztrajnosti, natančnosti, zanesljivosti), odprtost (težnja k iskanju novih izkušenj in zanimanju za druge kulture) in sprejemljivost (nagnjenost k sledenju pravil, družbenim normam in ohranjanju pozitivnih odnosov z drugimi). Metaanaliza (https://papers.ssrn.com/sol3/papers.cfm?abstract_id=3768022), v katero so bili vključeni rezultati 26 raziskav, je pokazala, da bolj ekstravertni, odprti in sprejemljivi posamezniki v večji meri sprejemajo robote, medtem ko povezava med nevroticizmom in vestnostjo ter pozitivnim sprejemanjem ni bila prepoznana. Podajmo se še na področje socialne psihologije, katere polje delovanja in raziskovanja je preučevanje človeka v socialnem kontekstu. Raziskovanje stališč je ena od osrednjih tem socialne psihologije, saj so stališča pomemben motivator našega vedenja. Kar je tuje, nepoznano in nepredvidljivo ljudje zaznavajo kot grožnjo. Pri tem se pojavijo občutki strahu, tesnobe in napetosti, ki lahko vodijo v oblikovanje negativnih stališč. Fenomen hipoteze stika predpostavlja, da ljudje preko osebnega stika nekaj spoznamo in tako nam ta »nekaj« ni več tuj, nepoznan in ogrožajoč. Osebni stik vpliva tudi na premik naših stališč v pozitivno smer. Podobno se zgodi tudi v interakciji z robotom. Ljudje, ki imajo pretekle izkušnje (https://dl.acm.org/doi/10.1145/3311788) z roboti, imajo do njih tudi bolj pozitivna stališča, neodvisno od starosti (https://dl.acm.org/doi/abs/10.1145/3311788). Pomemben vpliv na zaznavo, kako varen je človek v družbi robota, imajo tudi robotove fizične značilnosti. Če so gibi robota predvidljivi (https://hal.archives-ouvertes.fr/hal-01571944/document) in 
sledijo ustaljenim vzorcem gibov, bo posameznik ob tem zaznaval večjo stopnjo varnosti, saj robot tako izpolnjuje njegova pričakovanja o poteku interakcije oziroma sodelovanja. Nepredvidljivi

(https://www.tib.eu/en/search/id/elsevier:doi 10.1016\%252Fj.cirp.2010.03.043/Assessment-of-operator-stress-induced-byrobot?cHash=052584521838c806ff415a479d073162) gibi robota večinoma povzročajo negativna čustva, kar se kaže tudi v fizioloških reakcijah posameznika (npr. povišan utrip srca in močnejše potenje). Hitrejše

(https://onlinelibrary.wiley.com/doi/abs/10.1002/hfm.20703)ko je gibanje robota, večja sta psihofiziološki odziv posameznika in posameznikova zaznava nevarnosti. Zaznava varnosti gibanja robota je povezana tudi z njegovo velikostjo (https://onlinelibrary.wiley.com/doi/abs/10.1002/hfm.20058). Večji ko je robot, prej bo določena hitrost njegovega gibanja zaznana kot nevarna. Zaupanje $v$ robote narašča $s$ tem, ko robot učinkovito opravi določeno delovno nalogo. Če robot enkrat nalogo opravi dobro in naslednjič slabo, bo zaupanje upadlo.

Iz zgoraj navedenega lahko zaključimo, da pri sprejemanju robotov in oblikovanju pozitivnih stališčih do njih delujejo podobni psihološki in socialnopsihološki mehanizmi, kot delujejo pri sprejemanju drugih posameznikov, družbenih skupin in fizičnih predmetov. Predvidljivost, poznanost in občutek nadzora vselej vplivajo na večje zaupanje in občutek varnosti, saj so to evolucijske podstati našega delovanja.

\section{Soočanje s spremembami v organizaciji dela}

Trenutno smo priča vzniku četrte industrijske revolucije, ki se je začela ob prelomu v 21. stoletje in za katero so značilne velike tehnološke spremembe, strojno učenje, vseprisoten internet in umetna inteligenca (Schwab 2016 (https://frodx.com/cetrta-industrijska-revolucija/)). Za četrto industrijsko revolucijo je značilna tudi velika stopnja robotizacije. $V$ industriji 4.0 bodo začele prevladovati t. i. pametne tovarne, ki bodo temeljile na visoki oziroma popolni avtomatizaciji proizvodnje (Xu idr. 2018 (https://www.tandfonline.com/doi/abs/10.1080/00207543.2018.1444806) Posledično prodaja industrijskih robotov stalno raste, od leta 2009 se je vsako leto povečala za približno 14 odstotkov. Največji trg so Kitajska, Japonska, Južna Koreja, ZDA in Nemčija. Svetovni trg robotike naj bi bil leta 2020 vreden 103 milijarde ameriških dolarjev, leta 2025 pa naj bi se ta vrednost podvojila. Vsi trendi kažejo na pospešeno rast trga sodelujočih robotov, kar bo privedlo do njihovega vse večjega vključevanja na različna delovna mesta in tudi $v$ naše domove. Z vključevanjem sodelujočih robotov v organizacije se te neizogibno spremenijo. Pri uvajanju organizacijskih sprememb ( $v$ tem primeru (sodelujočih) robotov) v podjetja imajo ključno vlogo vodje podjetij. Odprta komunikacija $z$ zaposlenimi, skupno načrtovanje vključevanja robotov $v$ delovni proces, poslušanje in sprejemanje predlogov zaposlenih o načinu delovanja robotov in strokovno osebje, na katero se lahko zaposleni obrnejo v primeru težav, so ključni vidiki uspešnega vključevanja robotov na delovna mesta (Meissner idr. 2020 (https://dl.acm.org/doi/10.1145/3399433)).

\section{Sodelovanje za prihodnost}

Znan je izrek, da edino, kar je stalno v našem življenju, so spremembe. Ljudje se tem navadno izogibamo, saj od nas zahtevajo razvoj novih, spremenjenih vedenjskih vzorcev in strategij, kar seveda ni enostavno. Način dela se spreminja in tako se spreminjajo tudi same organizacije. $\vee$ prihodnosti bo sodelujočih robotov vedno več in že si lahko predstavljamo, kako bo sodelujoči robot namesto natakarja zlagal umazano posodo v pomivalni stroj in jo potem še zložil iz njega. Sodelujoči roboti nas lahko dodatno razbremenijo monotonega in ponavljajočega se dela, vendar je vselej pomembno kritično premisliti smiselnost in način vključevanja robotov na določena delovna in družbena področja. Uspešnost interakcije med človekom in robotom je odvisna od interdisciplinarnega sodelovanja strokovnjakov, ki prihajajo iz različnih družboslovno-humanističnih in naravoslovno-tehničnih ved.

* Prispevek je nastal v okviru projekta Collaborative Robot's Perceived Safety (CROPS), ki je financiran iz programa Horizon 2020 ter se izvaja na Oddelku za psihologijo Filozofske fakultete in Fakulteti za elektrotehniko Univerze v Ljubljani.

DOI: https://doi.org/10.3986/alternator.2021.30 (https://www.alternator.science/sl/daljse/psihologija-in-robotikanacrtovanje-interakcij-s-sodelujocim-robotom/) 